\title{
Hematological and Biochemical Evaluation of Dogs Undergoing Treatment with Veterinary Dental Gel for the Reduction of Plaque and Dental Calculus*
}

\author{
Lorena Priscila Oliveira Andrade', Nina Gabriela Silva Gualberto Oliveira', Fernanda Argôlo Magalhães², \\ Alexandre Dias Munhoz ${ }^{3}$, Amauri Arias Wenceslau ${ }^{3}$ \& Renata Santiago Alberto Carlos ${ }^{3}$
}

\begin{abstract}
Background: Periodontal disease affects a large proportion of dogs, causing both local and systemic symptoms. Several studies to identify alternative approaches for plaque reduction and removal have been conducted. Recently, Tropiclean Fresh Breath Clean Teeth Gel was introduced as an adjuvant to aid in plaque and calculus removal. This product is formulated using Aloe vera, green tea, and mint; however, studies on the toxic potential of this product have not been performed yet. The aim of this study was to evaluate the influence of Tropiclean Fresh Breath Clean Teeth Gel product on hematological and biochemical profiles in dogs undergoing 90-day treatment with the product.

Materials, Methods \& Results: Per manufacturers' recommendation, the product should be used daily for 30 consecutive days, and subsequently, as maintenance at two to three times a week. In this study, 48 dogs with periodontal disease who received prolonged daily treatment for 90 consecutive days underwent hematological and biochemical evaluation. During the 90 days' treatment duration, the animals were examined daily to identify the presence of adverse effects; and changes in halitosis were reported. At pre-treatment time-point, $5 \mathrm{~mL}$ of blood was collected via cephalic or jugular vein puncture in EDTA tubes for determining the complete blood count (CBC), and in tubes without EDTA for the urea, creatinine, and ALT levels; in addition, for comparison, blood was collected after 90 days' treatment. At post-treatment time-point, the hematological and biochemical analyses showed significantly lower total leukocyte count as compared to that at pretreatment $(P<0.01)$; comprising lower neutrophil count as the cell type involved $(P<0.05)$. The other parameters showed no statistically significant differences, demonstrating an absence of the products' effect in terms of alteration of these profiles. All the dogs showed absence of apathy, vomiting, diarrhea, reduced appetite, or abnormalities in the mucosal color; in addition, all showed improvement in halitosis; of which, 39 showed improvement at 1 weeks' treatment duration. Discussion: In the present study, the analyzed parameters were used to determine the hemolysis, leukocytes or platelet abnormalities, renal function, and liver injury. The kidneys and liver are organs that are closely linked to the metabolism and excretion of drugs; hence, their functions are often altered by the toxic effects of some substances. Despite the reported toxicity of Aloe vera, in the present study, there were no changes in the hematological and biochemical parameters in the dogs undergoing treatment for 90 days, except for the reduced total leukocyte count with differential reduction of the neutrophil population, indicating the products' safety at 90-days' treatment duration. The hematological and biochemical results were corroborated by the result of the absence of abnormal clinical signs at daily evaluation. In the dogs included in this study, the reduction of halitosis was associated with the reduction of the leukocyte count related to the bactericidal and bacteriostatic properties of the active ingredients of Aloe vera such as opirocatechol, cinnamic acid, ascorbic acid, and p-coumaric acid which were reported in the field of dentistry; and with regard to green tea, catechin galatoepigallocatechin (EgCG) may be responsible for the bactericidal and bacteriostatic effects. Thus, the product at 90 days' treatment duration showed safety, without changes in the hematological and biochemical profiles in the participating dogs.
\end{abstract}

Keywords: biochemical tests, complete blood count, veterinary dentistry, toxicity.

DOI: $10.22456 / 1679-9216.94861$

*Article based on a Thesis submitted by the senior author in partial fulfillment of requirements for the Master's degree. ${ }^{1}$ Animal Science (PPGCA); ${ }^{2}$ Veterinary Medicine Graduate \& ${ }^{3}$ Small Animal Clinic, Department of Agrarian and Environmental Sciences, Veterinary Medicine Course, State University of Santa Cruz (UESC), Ilhéus, BA, Brazil. CORRESPONDENCE: R.S.A. Carlos [rsacarlos@uesc.br]. Rua Lauro Farani de Freitas n. 101, ap.704. CEP 45.652-160 Ilhéus, BA, Brazil. 


\section{INTRODUCTION}

The study of plants with therapeutic properties has been gaining interest in the field of scientific research with promising results for the treatment of several diseases [17]. Recently, the Tropiclean Fresh Breath Clean Teeth Gel1 product comprising natural substances such as Aloe vera, green tea, and mint, was introduced for the purpose of promoting the removal of plaque and dental calculus without the need for brushing.

Aloe vera is a medicinal plant that has several reported therapeutic properties such as antibacterial, purifying, cleansing, anticancer, antifungal and antioxidant actions [20]. Hepatic lesions associated with its use may be associated with hypersensitivity, since the plant contains alkaloids that may induce hepatic enzymes, such as cytochrome $\mathrm{P} 450$, or interact with the autoimmune system [4,26,27].

Green tea contains catechins as the main therapeutic chemical component [18]. Excessive intake of green tea can cause side effects such as insomnia, waking state, nervousness, and tachycardia in sensitive individuals [22]; in addition, due to its ability to form a complex with metal ions, it can reduce the absorption of iron [22,23].

Hematological and biochemical profiles are routinely used to monitor the health status in dogs, quantify enzymes related to important organs in the metabolism and excretion of drugs [5], and identify alterations resulting from the exposure of some drug types.

The objective of this study was to evaluate the effect of treatment using Tropiclean Fresh Breath Clean Teeth $\mathrm{Gel}^{1}$ on the hematological and biochemical profiles in healthy dogs undergoing daily product application for 90 days.

\section{MATERIALS AND METHODS}

\section{Animals}

Forty-eight dogs from the clinical routine of the Veterinary Hospital of the State University of Santa Cruz (VH-UESC), Ilhéus, Bahia were included in the study.

The animals were selected through general and dental clinical evaluation. Inclusion criteria were dogs of age older than 1 year, any gender or race, body-weight up to $15 \mathrm{~kg}$, and with some degree of periodontal disease. Exclusion criteria were history of antibiotics usage, veterinary dental treatment, or domestic brushing at 3 months before starting treatment. In all dogs, permission to participate in the study was obtained from their owners.

\section{General and dental clinical evaluation}

For general clinical analysis, evaluation of the temperature, color of the mucosa, capillary filling time, and cardiopulmonary auscultation, abdomen and lymph nodes' palpation, and monitoring for occurrence of vomiting or diarrhea was performed.

Dental analysis was based on the observation of the presence of dental calculus in any dental element, and halitosis. In addition, the animals were classified according to the severity of periodontal disease, based on the presence of gingivitis associated with depth of the periodontal pockets through visual inspection and use of millimeter probe. Patients who presented with dental calculus, gingivitis, gingival sulcus depth $\leq 3$ $\mathrm{mm}$, and absence of dental root exposure were considered to have mild periodontal disease (G1); those with dental calculus, gingivitis, gingival sulcus depth $>3 \mathrm{~mm}$, and absence of dental root exposure were considered to have moderate periodontal disease $(\mathrm{G} 2)$; and those with changes as in G2 plus exposure of the dental root were considered to have severe periodontal disease (G3) [8]. Each group consisted of 16 animals.

\section{Application of veterinary dental gel}

In all included dogs, the application of Tropiclean Fresh Breath Clean Teeth Gel $^{1}$ was performed once a day at the owner's house by members of our team, during the 90-day period without interruption. The animals received no water or food $30 \mathrm{~min}$ before and after the application.

Gel of $2 \mathrm{~cm}$ length $(0.3 \mathrm{~mL}$ volume corresponding to $3 \mathrm{mg}$ of Aloe vera) was applied with the use of gloves directly to the plaque, dental calculus, and gingiva using the tip of the index finger and thumb. The application was performed with bilateral circular movements covering the dental surface.

\section{Collection of biological samples}

One day before the beginning of the gel treatment and 90 days after the start of the treatment, $5 \mathrm{~mL}$ of blood was collected via puncture of the cephalic or jugular vein; of which, $2 \mathrm{~mL}$ was placed in the tube with anticoagulant EDTA for $\mathrm{CBC}$, and $3 \mathrm{~mL}$ in 
the tube without anticoagulant for biochemical tests including the urea, creatinine and alanine aminotransferase (ALT) level. All samples were refrigerated until processing.

\section{Hematological and biochemical analysis}

CBC was performed using an automatic hematological counter (ABC Vet Automatic Blood Cell Counter $)^{2}$. Hematocrit was determined using the microhematocrit technique. Serum ALT, urea, and creatinine levels were determined using commercial kits from Labtest ${ }^{3}$ under reading with the semi-automatic biochemical analyzer BIO-2000 $\mathrm{IL}^{4}$.

We used the hematological and biochemical reference values reported by Kerr [10], and Tilley \& Smith Jr. [21].

\section{Clinical evaluation during treatment}

During the 90 days' treatment, the dogs underwent daily clinical evaluation for the body temperature, size of the lymph node, behavior, color of the mucosa, presence of vomiting or diarrhea, reduction in appetite, and halitosis.

\section{Data analysis}

For hematological and biochemical data, we used the analysis of variance (ANOVA) with confidence interval of $95 \%$.

\section{RESULTS}

The total leukocyte count showed significant reduction $(P<0.01)$ between treatment day 0 (mean, 12.82 leukocytes/ $\mu \mathrm{L}$ ), and day 90 (mean, 10.47 leukocytes $/ \mu \mathrm{L}$ ) [Table 1]; and the other hematological and biochemical parameters were within range of the reference values without significant differences.

Table 1. Mean and variance of the leukocyte count in 48 animals with applied veterinary dental at treatment day 0 and day 90 .

\begin{tabular}{ccccc}
\hline Day & $\mathrm{N}$ & Total & Mean & Variance \\
\hline 0 & 48 & 615.637 & $12.825 \mathrm{a}^{*}$ & 15.0987449 \\
90 & 48 & 502.8 & $10.475 \mathrm{~b}$ * & 13.01765957 \\
\hline
\end{tabular}

The neutrophils showed significant lower level between treatment day 0 and day $90(P<0.05)$, indicating primary role in contributing to the reduction in the total leukocyte count (Table 2); whereas, the differential counts of the other cell types were not significant between treatment day 0 and day 90 .
Table 2. Mean and variance of the neutrophil count in 48 animals with applied veterinary dental gel at treatment day 0 and 90 .

\begin{tabular}{ccccc}
\hline Day & $\mathrm{N}$ & Total & Mean & Variance \\
\hline 0 & 48 & 417482 & $8882.59 \mathrm{a}^{*}$ & 12106057.1156337 \\
90 & 48 & 357874 & $7614.34 \mathrm{~b}^{*}$ & 7782141.09898243 \\
\hline
\end{tabular}

In this study, all animals showed the absence of any adverse treatment effects such as fever or hypothermia, apathy, vomiting, diarrhea, reduced appetite, or altered mucosal color; 39 animals showed a reduction in halitosis at 1 weeks' gel application, which was additionally corroborated by the owners' observation at respective treatment period; the remaining nine animals showed reduced halitosis at 3 weeks' treatment. Patients with delayed reduction were of the severe periodontal disease group, suggesting the association with the higher bacterial load in the oral cavity.

\section{DISCUSSION}

There is limited reported data on the pharmacokinetics and toxicity of green tea and Aloe vera. In recent years, cases of toxic hepatitis in patients undergoing treatment with Aloe vera have been reported, indicating that even a medicinal plant may induce various toxic effects [26].

Regarding hematological parameters, our finding of the absence of anemia may be considered as an indirect index of toxicity, since green tea has the capacity to form complexes with metal ions, which can reduce iron absorption and consequently, cause anemia [22,23].

Many of the products' components have antibacterial properties. Significant leukocyte reduction involving reduced neutrophil count, which is associated with the reduction of halitosis, may be related to the bactericidal and bacteriostatic properties of the components of Aloe vera such as opirocatechol, cinnamic acid, ascorbic acid, and p-cumaric reported in the field of dentistry [19], thus reducing the bacterial population, and consequently, the leukocytic inflammatory response. With respect to green tea, the catechin galatoepigallocatechin (EgCG) mediated the bactericidal and bacteriostatic effect [7,11]. Alves et al. [2] reported the antibacterial activity of peppermint oil on Streptococcus mutans, S. mitis, and S. salivarius, common resident bacteria in the oral cavity. A report indicated that mint had antibacterial effect, inhibiting formation of the dental biofilm [15]. In addition to its 
anti-bacterial effects, antifungal and antioxidant activity were reported [13].

In our study, the urea and creatinine levels at pretreatment time-point were within normal range, and these parameters were maintained within the normal range at day 90 , suggesting the absence of toxic renal damage, since the kidney is considered as the main site of toxic excretion in the body $[6,24]$.

Moreover, our results indicated the absence of changes in the ALT level. In humans, 3 months' treatment using Aloe vera at dose ranging from 28.5 to 420 mg daily, with the lowest dose associated with Aloe arborescents extract of $250 \mathrm{mg}$ daily, showed toxicity and increase in the ALT level [26]. The present study showed that the dose of Aloe vera through application of the product for 90 days caused no changes in the ALT level, indicating its safety for use in dogs.

Our results are corroborated by the results of another experimental study [27] including an in vivo mouse model orally administered UP780, a compound extracted from the leaf of Aloe vera. With regard to acute toxicity, the authors reported that the dose of 2 $\mathrm{g} / \mathrm{kg}$ daily for 14 days; and 100, 500 and $1000 \mathrm{mg} / \mathrm{kg}$ daily, in sequence, for additional 90 days showed the absence of signs of morbidity, mortality, or toxicity [27]; as compared to the reported toxicity of Aloe vera in humans which may involve compounds other than UP780. In our study, the product at the indicated dose for 90 days' treatment duration showed safety.

In our study, there was absence of clinical abnormalities; whereas, alterations in the clinical signs related to the presence of acute toxic liver and kidney lesions generally include the enlarged lymph nodes, jaundice, anemia, vomiting, and diarrhea [14].

In all dogs included in our study, halitosis was rapidly reduced. Mint, as part of the product formulation, comprises components such as menthol, mentone, and cineole [25]. Based on these characteristics, it is widely used in the cosmetics and medicine industry as flavoring agent in various products, attributing characteristic flavor and refreshing aroma [12]. Halitosis is a result of the tissue necrosis and release of volatile sulfur compounds due to microbial metabolism; hence, it is associated with the bacterial concentration in the oral cavity [1]. These bacteria may directly influence the increase or decrease of inflammatory cells [9]. The reduction in halitosis may be related to the green tea and/or Aloe vera-mediated reduction of the oral bacterial population, and total leukocyte count, despite the finding of values within reference range for the species; in addition, it is likely that mint had influence to enhance fresh breath through its striking odor, thus resulting in the combined mechanistic effect $[3,16]$.

\section{CONCLUSION}

The use of the gel product at 90 days' treatment duration, under the conditions of this work, acted showed effectiveness to reduce the number of neutrophils, total leukocytes, and halitosis, with the absence of clinical and laboratory alterations associated with poisoning.

\section{MANUFACTURERS}

${ }^{1}$ Tropiclean. Wentzville, MO, USA.

${ }^{2}$ Horiba Instruments Brasil Ltda. Jundiaí, SP, Brazil.

${ }^{3}$ Labtest. Lagoa Santa, MG, Brazil.

${ }^{4}$ Bioplus Produtos para Laboratórios Ltda. Barueri, SP, Brazil.

Funding. This research was supported by State University of Santa Cruz (UESC), by Tropiclean and Bioctal Comercio de Produtos Veterinários Ltda. This study was financed in part by the Coordenação de Aperfeiçoamento de Pessoal de Nível Superior - Brasil (CAPES) - Finance Code 001.

Acknowledgments. We would like to thank State University of Santa Cruz (UESC), Coordenação de Aperfeiçoamento de Pessoal de Nível Superior (CAPES) and Fundação de Amparo à Pesquisa do Estado da Bahia (FAPESB) for granting us scholarships.

Ethical approval. This study was approved by the Ethics Committee for the Use of Animals of the State University of Santa Cruz (protocol no. 022/2014).

Declaration of interest. The authors report no conflicts of interest. The authors alone are responsible for the content and writing of the paper.

\section{REFERENCES}

1 Aljateeli M., Giannobile W.V. \& Wang H.L. 2013. Locally-delivered antibiotics for management of periodontitis: current understanding. The Journal of the Michigan Dental Association. 95(7): 42-47.

2 Alves L.A., Freires I.A. \& Castro R.D. 2010. Efeito Antibacteriano de Óleos Essenciais sobre Bactérias Formadoras do Biofilme Dentário. Revista Brasileira de Ciências da Saúde. 14(2): 57-62.

3 Amorim J.A., Lins R.D.A.U., Souza A.D., Alves R.D., Maciel M.A.S. \& Lucena R.N. 2010. Aspectos epidemiológicos e etiológicos da halitose: considerações recentes. Revista Brasileira de Odontologia. 67(1): 76-80. 
4 Bottenberg M.M., Wall G.C., Harvey R.L. \& Habib S. 2007. Oral Aloe vera-Induced Hepatitis. The Annals of Pharmacotherapy. 41(10): 1740-1743.

5 Brenten T., Morris P.J., Salt C., Raila J., Kohn B., Schweigert F.J. \& Zentek J. 2016. Age-associated and breedassociated variations in haematological and biochemical variables in young Labrador retriever and miniature schnauzer dogs. Veterinary Record Open. 3(1): 1-9.

6 Camargo M.H.B., Moraes J.R.E., Carvalho M.B., Ferraro G.C. \& Borges V.P. 2006. Alterações morfológicas e funcionais dos rins de cães com insuficiência renal crônica. Arquivo Brasileiro de Medicina Veterinária e Zootecnia. 58(5): 781-787.

7 Das S., Mishra B., Giil K., Ashraf M.S., Singh A.K., Sinha M., Sharma S., Xess I., Dalal K., Singh T.P. \& Dey S. 2011. Isolation and characterization of novel protein with anti-fungal and anti-inflammatory properties from Aloe vera leaf gel. International Journal of Biological Macromolecules. 48(1): 38-43.

8 Di Bello A., Buonavoglia A., Franchini D., Valastro C., Ventrella G., Greco M.F. \& Corrente M. 2014. Periodontal disease associated with red complex bacteria in dogs. Journal of Small Animal Practice. 55(3): 160-163.

9 Harvey C.E. 1998. Periodontal disease in dogs - Etiopathogenesis, prevalence and significance. Veterinary Clinics of North America: Small Animal Practice. 28(5): 1111-1128.

10 Kerr M.G. 2003. Exames laboratoriais em medicina veterinária : bioquímica clínica e hematologia. São Paulo: Roca, 436p.

11 Lawrence R., Tripathi P. \& Jeyakumar E. 2009. Isolation, purification and evaluation of antibacterial agents from Aloe vera. Brazilian Journal of Microbiology. 40(4): 906-915.

12 Martins R.S., Macedo J.B., Muniz F.W.M.G., Carvalho R.S. \& Moreira M.M.S.M. 2012. Composição, princípios ativos e indicações clínicas dos dentifrícios: uma revisão de literatura entre 1989 e 2011. Journal of the Health Sciences Institute. 30(3): 287-291.

13 Matos B.M., Komiyama E.Y., Balducci I. \& Koga-ito C.Y. 2009. Atividade antifúngica do extrato alcoólico de Mentha piperita sobre Candida albicans e C. tropicalis. Revista de Odontologia da UNESP. 38(4): 244-248.

14 Nogueira R.M.B. \& Andrade S.F. 2011. Manual de Toxicologia Veterinária. São Paulo: Roca, 336p.

15 Rasooli I., Shayegh S. \& Astaneh S. 2009. The effect of Mentha spicata and Eucalyptus camaldulensis essential oils on dental biofilm. International Journal of Dental Hygiene. 7(3): 196-203.

16 Rösing C.K. \& Loesche W. 2011. Halitosis: an overview of epidemiology, etiology and clinical management. Brazilian Oral Research. 25(5): 466-471.

17 Santos N.S., Carlos R.S.A. \& Albuquerque G.R. 2012. Doença Periodontal em Cães e Gatos. Revisão de Literatura. Medvep - Revista Científica de Medicina Veterinária - Pequenos Animais e Animais de Estimação. 10(32): 1-12.

18 Senger A.E.V., Schwanke C.H.A. \& Gottlieb M.G.V. 2010. Chá verde (Camellia sinensis) e suas propriedades funcionais nas doenças crônicas não transmissíveis. Scientia Medica. 20(4): 292-300.

19 Tamura N., Yoshida T., Miyaji K., Sugita-Konishi Y. \& Hattori M. 2009. Inhibition of infectious diseases by components from Aloe vera. Bioscience, Biotechnology, and Biochemistry. 73(4): 950-953.

20 Tayal E., Sardana D., InduShekar K.R., Saraf B.G. \& Sheoran N. 2014. Current Perspectives on Use of Aloe vera in Dentistry. European Journal of Medicinal Plants. 4(12): 1408-1419.

21 Tilley L.P. \& Smith Jr. F.W.K. 2002. Valores Bioquímicos normais. In: Consulta veterinária em 5 minutos: espécies canina e felina. São Paulo: Manole, pp.1324-1397.

22 Valenzuela A.B. 2004. El consumo te y la salud: características y propriedades benéficas de esta bebida milenaria. Revista Chilena de Nutrición. 31(2): 72-82.

23 Vieiro T., Ferraz A., Rates S.M.K. \& Poser G.L.V. 2005. Efeitos benéficos e adversos decorrentes do consumo do chá preparado com folhas de Camellia Sinensis. Boletim da Sociedade Brasileira de Ciência e Tecnologia de Alimentos. 37: 40-45.

24 Waki M.F., Martorelli C.R., Mosko P.E. \& Kogika M.M. 2010. Classificação em estágios da doença renal crônica em cães e gatos - abordagem clínica, laboratorial e terapêutica. Ciência Rural. 40(10): 2226-2234.

25 Watanabe C.H., Nosse T.M., Garcia C.A. \& Pinheiro Povh N. 2006. Extração do óleo essencial de menta (Mentha arvensis L.) por destilação por arraste a vapor e extração com etanol. Revista Brasileira de Plantas Medicinais. 8(4): 76-86.

26 Yang H.N., Kim D.J., Kim Y.M., Kim B.H., Sohn K.M., Choi M.J. \& Choi Y.H. 2010. Aloe-induced Toxic Hepatitis. Journal of Korean Medical Science. 25(3): 492-495.

27 Yimam M., Brownell L. \& Jia Q. 2014. In vivo safety evaluation of UP780, a standardized composition of aloe chromone aloesin formulated with an Aloe vera inner leaf fillet. Regulatory Toxicology and Pharmacology. 69(3): 390-397. 